\title{
Permainan Tradisional Dalam Pembelajaran Pendidikan Jasmani untuk Meningkatkan Kebugaran dan Motivasi Belajar
}

\author{
Nuriska Subekti ${ }^{1 凶}$, Agus Mulyadi $^{2} \&$ Juhrodin \\ Universitas Siliwangi, nuriskasubekti@unsil.ac.id
}

\begin{abstract}
Article Info
History Articles

Received : 3 Mei 2020

Accepted : 9 Mei 2020

Published : 20 Mei 2020

\section{Keywords}

strategi pembelajaran; permainan tradisional; kebugaran jasmani; motivasi belajar.

Abstrak

Tujuan dalam penelitian ini untuk mendapatkan informasi mengenai kebugaran jasmani serta motivasi belajar siswa sebagai salah satu upaya untuk mengembangkan semua potensinya secara optimal, baik potensi fisik serta motivasi belajar pada anak sekolah dasar melalui permainan tradisional. Penelitian ini menggunakan metode penelitian eksperimen. Populasi dalam penelitian ini adalah siswa-siswi SD Islam Al Jamal Kota Tasikmalaya dengan populasi 268 orang. Sampel penelitian ini adalah kelas V dengan jumlah 30 orang putra dan putri. Instrumen yang digunakan dalam penelitian ini yaitu kebugaran jasmani serta motivasi belajar siwa yang dianalisis dengan menggunakan program excel 2016. Berdasarkan hasil analisis uji paired sample t tes, pada variabel tes kebugaran diperoleh nilai signifikansi sebesar 0,45 , nilai tersebut diatas nilai alpha $(0,45>0,05)$, artinya permainan tradisional tidak memberikan pengaruh yang signifikan terhadap peningkatan kebugaran jasmani. Berdasarkan hasil analisis uji paired sample t tes, pada variabel motivasi diperoleh nilai signifikansi sebesar 0,00 , nilai tersebut dibawah nilai aplha $(0,00<0,05)$, artinya permainan tradisional memberikan pengaruh yang signifikan terhadap pengembangan Motivasi Belajar.
\end{abstract}

\begin{abstract}
The purpose of this study was to obtain information about physical fitness and student learning motivation as an effort to develop all of its potential optimally, both physical potential and motivation to learn in elementary school children through traditional games. This study uses an experimental research method. The population in this study were students of Al Jamal Islamic Elementary School in Tasikmalaya City with a population of 268 people. The sample of this study was class $V$ with a total of 30 men and women. The instruments used in this study were physical fitness and student learning motivation which were analyzed using the 2016 excel program. Based on the results of paired sample $t$ test analysis, the fitness test variable obtained a significance value of 0.45 , the value is above alpha $(0$, $45>0.05)$, meaning that traditional games do not have a significant effect on improving physical fitness. Based on the results of paired sample t test analysis, the motivation variable obtained a significance value of 0.00 , the value is below the value of aplha $(0.00<0.05)$, meaning that traditional games have a significant influence on the development of Learning Motivation.
\end{abstract}




\section{PENDAHULUAN}

Pendidikan jasmani adalah suatu proses pendidikan seseorang sebagai perorangan atau anggota masyarakat yang dilakukan secara sadar dan sistematik melalui berbagai kegiatan jasmani untuk memperoleh pertumbuhan jasmani, kesehatan dan kesegaran jasmani, kemampuan dan keterampilan, kecerdasan dan perkembangan watak serta kepribadian yang harmonis. Menurut Samsudin (2014: 54) bahwa "Pendidikan jasmani adalah suatu proses pembelajaran melalui aktivitas jasmani yang didesain untuk meningkatkan kebugaran jasmani, mengembangkan keterampilan motorik, pengetahuan dan perilaku hidup sehat dan aktif, sikap sportif, dan kecerdasan emosi".

Dapat disimpulkan bahwa pendidikan jasmani merupakan proses pendidikan yang memanfaatkan aktivitas jasmani dan direncanakan secara sistematik bertujuan untuk meningkatkan individu secara organik, neuromoskuler, perseptual, kognitif, sosial dan emosional. Adapun tujuan dari pendidikan jasmani menurut Samsudin (2014 : 54) adalah; (1) meletakkan landasan karakter yang kuat melalui internalisasi nilai dalam pendidikan jasmani, (2) membangun landasan kepribadian yang kuat, sikap cinta damai, sikap sosial dan toleransi dalam konteks kemajemukan budaya, etnis, dan agama, (3) menumbuhkan kemampuan berfikir kritis melalui tugas-tugas pembelajaran pendidikan jasmani, mengembangkan sikap sportif, jujur, disiplin, bertanggung jawab, kerjasama, percaya diri, dan demokratis melalui aktivitas jasmani, (5) mengembangkan keterampilan gerak dan keterampilan teknik serta strategi berbagai permainan dan olahraga, aktivitas pengembangan, senam, aktivitas ritmik, akuatik (aktivitas air), dan pendidikan luar kelas (outdoor education), (6) mengembangkan keterampilan pengelolaan diri dalam upaya pengembangan dan pemeliharaan kebugaran jasmani serta pola hidup sehat melalui berbagai aktivitas jasmani, (7) mengembangkan keterampilan untuk menjaga keselamatan diri sendiri dan orang lain, (8) mengetahui dan memahami konsep aktivitas jasmani sbagai informasi untuk mencapai kesehatan, kebugaran dan pola hidup sehat, dan (9) mampu mengisi waktu luang dengan aktivitas jasmani yang bersifat rekreatif.

Dengan demikian, tujuan dari pendidikan jasmani adalah untuk mengembangkan kondisi fisik, mental sosial, moral, spiritual dan intelektual dengan berbagai aktivitas pendidikan jasmani yang ada. Tujuan utama dari pendidikan jasmani adalah memperoleh dan mempertahankan derajat kebugaran jasmani yang optimal. Istilah kebugaran jasmani sepertinya sudah tidak asing lagi bagi kita, terlebih bagi para pemerhati kemajuan dunia olahraga. Kebugaran jasmani sesuai dengan kata asalnya yaitu: physical fitness atau kesehatan fisik. Seperti yang telah di kemukakan menurut Laelatul Badriah, Dewi (2014: 31) kebugaran jasmani adalah "kemampuan tubuh dalam melakukan berbagai macam pekerjaan tanpa mengalami kelelahan yang berarti dan dapat segera pulih sebelum datangnya tugas pada keesokan harinya.".

Kebugaran jasmani merupakan hal sangat penting bagi siswa. Dengan mempunyai kebugaran jasmani yang baik maka siswa dapat melakukan berbagai macam pekerjaan tanpa mengalami kelelahan yang berarti dan dapat segera pulih sebelum datangnya tugas pada keesokan harinya. Dengan demikian kebugaran jasmani penting diterapkan pada proses pembelajaran.

Selain kebugaran jasmani untuk dapat meningkatkan minat siswa dalam proses 
pembelajaran yaitu motivasi. Mengenai motivasi menurut Komarudin (2017:24) "Motivasi dapat didefinisikan sebagai dorongan yang berasal dari dalam atau dari luar diri individu untuk melakukan suatu aktifitas yang bisa menjamin kelangsungan aktifitas tersebut, serta dapat menentukan arah, haluan dan besaran upaya yang di kerahkan untuk melakukan aktifitas sehingga dapat mencapai tujuan yang telah ditetapkan". Motivasi merupakan salah satu faktor penting yang mempengaruhi belajar dan hasil belajar seseorang yang memiliki motivasi kecenderungan untuk mencurahkan segala kemampuannya untuk menghasilkan hasil belajar yang optimal sesuai dengan hasil belajar yang diharapkan. Semakin tinggi motivasi yang dimiliki siswa akan mendorong siswa belajar lebih giat lagi dan frekuensi belajarnya menjadi semakin meningkat.

Motivasi belajar dapat timbul karena faktor intrinsik (faktor yang berasal dari dalam), berupa hasrat dan keinginan berhasil dan dorongan kebutuhan akan belajar, harapan akan cita-cita. Sedangkan faktor ekstrinsiknya (dari luar) adalah adanya penghargaan, adanya lingkungan belajar yang kondusif dan kegiatan belajar yang menarik. Akan tetapi harus diingat, kedua faktor tersebut disebabkan oleh rangsangan tertentu, sehingga individu atau seseorang berkeinginan untuk melakukan aktivitas belajar yang lebih giat dan semangat. Siswa yang bermotivasi tinggi dalam belajar memungkinkan akan memperoleh hasil belajar yang lebih tinggi pula, artinya semakin tinggi motivasinya semakin intensitas usaha dan upaya yang dilakukan, maka semakin tinggi hasil belajar yang diperolehnya. Siswa melakukan usaha atau upaya untuk meningkatkan keberhasilan dalam belajar sehingga mencapai keberhasilan yang cukup memuaskan sebagaimana yang diharapkan.
Dari hasil observasi yang dilakukan pada salah satu sekola dasar swasta yang berada di Kota Tasikmaya penulis melihat kurangnya sarana prasarana dalam proses pembelajaran penjas. kurangnya sarana dan prasarana tersebut dapat mempersulit guru dalam proses belajar mengajar penjas, sehingga tidak dapat dengan mudah mengembangkan pengetahuan, kurangnya mengembangkan keterampilan motorik serta kurang meningkatnya kebugaran jasmani. Selain itu dengan kurangnya sarana dan prasarana tersebut membuat motivasi belajar siswa kurang begitu berantusias, sehingga siswa kurang melakukan usaha atau upaya untuk meningkatkan keberhasilan dalam belajar yang mengakibatkan tidak tercapainya keberhasilan yang memuaskan sebagaimana yang diharapkan.

Dari paparan masalah di atas kita harus lebih kreatif dan inovatif untuk membuat strategi pembelajaran penjas dengan segala keterbatasan sarana dan prasarana yang dimiliki sekolah. Strategi pembelajaran menurut Sanjaya, Wina (2007 :126) "Strategi pembelajaran dapat diartikan sebagai perencanaan yang berisi tentang rangkaian kegiatan yang didesain untuk mencapai tujuan pendidikan tertentu". Strategi pembelajaran yang dimaksudkan untuk mencapai tujuan pembelajaran penjas tersebut yaitu dengan permainan tradisional. Permainan tradisional menurut Kusmaedi, Nurlan (2010 :vi) "Permaianan tradisional adalah permainan yang dimainkan oleh anak-anak dengan alat-alat yang sederhana, tanpa mesin, asalkan anak tersebut sehat, maka ia bias ikut bermain".

Melalui permainan tradisional, anak-anak juga dapat mengembangkan semua potensinya secara optimal, baik potensi fisik yang berhubungan dengan kecerdasan gerakkinestetik, mental intelektual dan spiritual. 
Permainan tradisional yang penulis ungkap hanya permainan yang ada aktifitas fisik sesuai dengan permasalah yaitu untuk meningkatkan kebugaran siswa. Permainan tradisional yang banyak aktifitas fisiknya yaitu permainan kinestetik dan permainan ketangkasan.

Permainan kinestetik menurut Sumitra 2017:24) "permainan kinestetik melatih kita untuk mengembangkan kemampuan fisiknya. Meliputi koordinasi, keseimbangan, keterampilan, kekuatan, kelentukan, kecepatan, dan kemampuan menerima rangsangan panca indera". Beberapa permainan kinestetik yang dapat dimainkan seperti boy-boyan, oray-orayan, galah asih/gobak sodor, ucing-ucingan, ucing sumput. Permainan ketangkasan menurut Sumitra (2017 :74) "permainan ketangkasan adalah permainan yang bentujuan untuk mengembangkan kecerdasan motorik pemainnya". Beberapa permainan ketangkasan seperti gatrik akod, jajangkungan/egrang, luncat tali, sapintrong, sorodot gaplok.

Oleh karena itu, melalui permainan tradisional (permainan kinestetik, permainan ketangkasan) bagi anak usia dini merupakan jembatan berkembangnya semua aspek khususnya aktifitas fisik. Dengan demikian jelas bahwa permainan tradisional khususnya permainan kinestetik dan permainan ketangkasan dalam pembelajaran penjas nantinya mampu meningkatkan kebugaran jasmani serta motivasi belajar siswa.

Berdasarkan uraian di atas peneliti tertarik untuk mengadakan penelitian dengan judul "Strategi pembelajaran melalui permainan tradisional dalam pembelajaran penjas terhadap peningkatan kebugaran jasmani serta motivasi belajar siswa Sekolah Dasar di Kota Tasikmalaya".

\section{METODE}

Sesuai dengan permasalahan penelitian ini, maka jenis penelitian ini adalah eksperimen karena sifat dari penelitian ini, adalah untuk mengungkapkan strategi pembelajaran melalui permainan tradisional dalam pembelajaran penjas terhadap peningkatan kebugaran jasmani serta motivasi belajar siswa Sekolah Dasar di Kota Tasikmalaya.

Mengenai metode eksperimen menurut Sugiyono (2015:107) "Metode penelitian yang digunakan untuk mencari pengaruh perlakuan tertentu terhadap yang lain dalam kondisi yang terkendalikan". Setiap penelitian harus menggunakan pola atau metode tertentu yang menjadi suatu keharusan dalam penelitian. Demikian pula dalam penelitian yang dilakukan ini. Pada penelitian ini diharapkan adanya penjelasan mengenai hubungan-hubungan sebab akibat dari kedua variabel yang sedang diteliti. Permasalahan yang ingin diteliti pada penelitian ini adalah "Strategi pembelajaran melalui permainan tradisional dalam pembelajaran penjas terhadap peningkatan kebugaran jasmani serta motivasi belajar siswa Sekolah Dasar di Kota Tasikmalaya".

Saat melakukan penelitian seorang peneliti memerlukan suatu metode sebagai salah satu cara untuk mencapai tujuan penelitian dan membantu mengungkapkan suatu permasalahan. Keberhasilan suatu penelitian ilmiah tidak terlepas dari metode yang digunakan dalam penelitian. Masalah yang diteliti serta tujuan yang ingin dicapai dalam suatu penelitian akan menentukan penggunaan metode penelitian.

Untuk membuktikan kebenaran dan menguji hipotesis yang penulis ajukan penulis melakukan penelitian dengan menggunakan metode exsprimen, yaitu mengadakan percobaan-percobaan terhadap variable-variabel 
yang diselidiki untuk mendapatkan suatu hasil. Menurut Ruseffendi (2005:32) bahwa "Penelitian eksperimen atau percobaan (experimental research) adalah penelitian yang benar-benar untuk melihat hubungan sebab akibat."

Populasi adalah objek penelitian atau yang dijadikan sumber data dari suatu penelitian. Populasi memegang peranan penting dalam suatu penelitian, sebab populasi merupakan objek yang akan dipergunakan sebagai bahan penelitian, Populasi dalam penelitian ini adalah siswa-siswi SD Islam Al Jamal Jl Pamijahan Kel.Sukarindik Kec.Bungursari kota Tasikmalaya dengan jumlah populasi 268 orang.

Sampel adalah sebagian atau wakil populasi yang diteliti. Arikunto (2006: 131) menjelaskan pengertian sampel sebagai berikut: "Sampel adalah sebagian atau wakil populasi yang diteliti". Sesuai dengan penjelasan tersebut penulis memilih dan menentukan sebagian populasi untuk dijadikan sampel penelitian, penentuan sampel dimaksudkan untuk mengurangi subjek yang terlalu banyak jumlahnya. Penentuan sampel ini dilakukan dengan teknik purposive sampling sesuai dengan tujuan penelitian maka sampel yang di ambil adalah siswa- siswi yang mempunyai kebugaran serta motivasi belajar yang kurang. Mengenai banyaknya sampel eksperimen yang diambil untuk penelitian ini adalah kelas $\mathrm{V}$ SD Islam AI Jamal Jl Pamijahan Kel.Sukarindik Kec.Bungursari kota Tasikmalaya dengan jumlah 32 orang putra dan putri..

Metode pengumpulan data ialah teknik atau cara-cara yang dapat digunakan oleh peneliti untuk pengumpulan data. Menurut Natsir (2003:328) dalam Riduwan (2009:72) mengatakan bahwa 'Teknik mengumpulan data merupakan alat-alat ukur yang diperlukan dalam melaksanakan suatu penelitian.' Teknik pengumpulan data yang digunakan dalam penelitian ini yaitu tes uji angket.

Analisis data dilaksanakan dengan menggunakan program exel 2016. Adapun langkah-langkah yang ditempuh yaitu deskripsi data melalui rekapitulasi dan tabulasi data, dari cara tersebut dilanjutkan kepada uji normalitas data, uji homogenitas data dan uji rata-rata dengan uji-t.

Uji normalitas data dilaksanakan dengan tujuan agar dapat memperoleh informasi mengenai distribusi kenormalan data. Selain itu, uji normalitas data juga akan menentukan langkah yang harus ditempuh selanjutnya, yaitu analisis statistik apa yang harus digunakan, apakah statistik parametrik atau non-parametrik. Langkah yang dilakukan adalah dengan menginput dan menganalisa menggunakan exel 2016.

Uji homogenitas data dilaksanakan setelah uji normalitas data. Tujuan uji homogenitas data adalah untuk mengetahui apakah data tersebut berasal dari sampel atau populasi yang homogen atau tidak. Selain itu juga untuk menentukan jenis analisis statistik apa yang selanjutnya digunakan dalam uji hipotesis data. Karena syarat dari uji satistik parametrik, data penelitian harus berdistribusi normal dan homogen.

Uji hipotesis data dilakukan guna mendapatkan kesimpulan dari data yang diperoleh. Jenis analisis statistik yang digunakan untuk melakukan uji hipotesis dalam rangka mencari kesimpulan ditentukan oleh hasil uji normalitas dan homogenitas data. Pengujian dilakukan untuk mengetahui apakah ada pengaruh yang signifikan dari strategi pembelajaran menggunakan metode bermain kooferatif dalam pembelajaran penjas terhadap perkembangan sosial anak. 
Uji hipotesis dilakukan untuk menguji nilai rata-rata (compare means) pada exel 2016. Untuk mengolah hasil tes awal dan tes akhir yang digunakan analisis dengan paired sampel t-test.

\section{HASIL DAN PEMBAHASAN}

Pada bab ini diuraikan data hasil penelitian dengan menggunakan uji - $t$, termasuk didalamnya untuk yang dua sampel independent, dua sampel berpasangan, dan uji-t satu sampel. Selanjutnya dilakukan analisis dan pembahasan hasil pengolahan statistik dengan beberapa tahapan yaitu deskripsi data, hasil uji normalitas data, hasil uji homogenitas data, dan hasil uji dua rata-rata dengan uji-t.Untuk uji-t disajikan dua pengujian, yaitu paired sample t-test dilakukan untuk mengetahui pengaruh signifikansi hasil tes Sebelum dan tes sesudah pada kebugaran serta motivasi belajar siswa.

\section{Deskripsi Data}

Deskripsi data menyajikan hasil pengolahan data secara deskriptif yang disajikan dalam bentuk tabel.

Tabel 1. Tes Sebelum dan Sesudah diberikan perlakuan permainan tradisional

Paired Samples Statistics

\begin{tabular}{cccccc}
\hline & & Mean & $N$ & Std. Deviation & $\begin{array}{c}\text { Std. Error } \\
\text { Mean }\end{array}$ \\
\hline Pair 1 & Pre Test Kebugaran & 11,47 & 32 & 2,02 & 0,36 \\
\cline { 2 - 6 } & Post Test Kebugaran & 11,22 & 32 & 2,70 & 0,48 \\
\hline Pair 2 & VAR00003 & 136,06 & 32 & 10,02 & 1,77 \\
\cline { 2 - 6 } & VAR00004 & 151,97 & 32 & 12,24 & 2,16 \\
\hline
\end{tabular}

Paired Samples Correlations

\begin{tabular}{ccccc}
\hline & N & Correlation & Sig. \\
\hline Pair 1 & $\begin{array}{c}\text { Pre Test Kebugaran \& Post Test } \\
\text { Kebugaran }\end{array}$ & 32 & 0,72 & 0,00 \\
\hline Pair 2 & VAR00003 \& VAR00004 & 32 & 0,58 & 0,00 \\
\hline
\end{tabular}

Paired Samples Test

\begin{tabular}{|c|c|c|c|c|c|c|c|c|c|}
\hline & & \multicolumn{5}{|c|}{ Paired Differences } & \multirow[b]{4}{*}{$\mathrm{t}$} & \multirow[b]{4}{*}{$d f$} & \multirow{4}{*}{$\begin{array}{l}\text { Sig. }(2 \\
\text { tailed) }\end{array}$} \\
\hline & & \multirow[b]{3}{*}{ Mean } & \multirow{3}{*}{$\begin{array}{c}\text { Std. } \\
\text { Deviation }\end{array}$} & \multirow{3}{*}{$\begin{array}{l}\text { Std. } \\
\text { Error } \\
\text { Mean }\end{array}$} & \multirow{2}{*}{\multicolumn{2}{|c|}{$\begin{array}{l}95 \% \text { Confidence } \\
\text { Interval of the } \\
\text { Difference }\end{array}$}} & & & \\
\hline & & & & & & & & & \\
\hline & & & & & Lower & Upper & & & \\
\hline \multirow[t]{2}{*}{ Pair 1} & Pre Test & & & & & & & & \\
\hline & $\begin{array}{c}\text { Kebugaran - Post } \\
\text { Test Kebugaran }\end{array}$ & 0,25 & 1,87 & 0,33 & $(0,42)$ & 0,92 & 0,76 & 31 & 0,45 \\
\hline Pair 2 & $\begin{array}{c}\text { Pre Motivasi \& } \\
\text { Post Motivasi }\end{array}$ & $(15,91)$ & 10,38 & 1,83 & $(19,65)$ & $(12,16)$ & $(8,67)$ & 31 & 0,00 \\
\hline
\end{tabular}

Berdasarkan hasil analisis uji paired sample $t$ tes, pada variabel tes kebugaran diperoleh nilai signifikansi sebesar 0,45 , nilai tersebut diatas nilai aplha $(0,45>0,05)$, artinya permainan tradisional 
tidak memberikan pengaruh yang signifikan terhadap peningkatan kebugaran jasmani.

Berdasarkan hasil analisis uji paired sample $\mathrm{t}$ tes, pada variabel motivasi diperoleh nilai signifikansi sebesar 0,00 , nilai tersebut dibawah nilai aplha $(0,00<0,05)$, artinya permainan tradisional memberikan pengaruh yang signifikan terhadap pengembangan Motivasi Belajar.

\section{Pembahasan}

Dalam bagian ini penulis akan membahas hasil pengujian hipotesis yang dilakukan dengan menggunakan statistik. Pengujian hipotesis tersebut dilakukan untuk menjawab permasalahan penelitian atau hipotesis yang penulis ajukan.

Mengajar merupakan bagian dari proses pendidikan dan mengajar itu merupakan seni karena ketika guru memberikan bahan ajar maka perlu menerapkan dan mempraktikan pola dan dasar (prinsip) yang telah dipelajari, artinya mengajar merupakan pemilihan dan aplikasi aturan-aturan yang tepat atau sesuai dengan situasi dan kerakteristis siswa tertentu. Lepas dari dimensi mengajar, unsur yang sangat penting dalam mengajar ialah merangsang serta mengarahkan siswa belajar. Hal tersebut dapat terlaksana jika guru atau pengajar menggunakan modivikasi pembelajaran yang tepat, disesuaikan dengan perkembangan dan karakteristik siswa yang akan menjalani proses pembelajaran tersebut.

Berdasarkan hasil dari pengolahan data dan analisis diatas strategi pembelajaran menggunakan permainan tradisional dalam pembelajaran penjas memberikan pengaruh yang signifikan terhadap siswa kelas V SD Islam Al Jamal Jl Pamijahan Kel.Sukarindik Kec.Bungursari kota Tasikmalaya.

\section{KESIMPULAN DAN REKOMENDASI}

Berdasarkan hasil penelitian tentang "Strategi pembelajaran melalui permainan tradisional dalam pembelajaran penjas terhadap peningkatan kebugaran jasmani serta motivasi belajar siswa Sekolah Dasar di Kota Tasikmalaya" dapat penulis simpulkan Strategi pembelajaran melalui permainan tradisional dalam pembelajaran penjas memberikan pengaruh yang signifikan terhadap peningkatan kebugaran jasmani serta motivasi belajar siswa kelas V SD Islam Al Jamal Jl Pamijahan Kota Tasikmalaya artinya melalui permainan tradisional (permainan kinestetik, permainan ketangkasan) bagi anak usia dini merupakan jembatan berkembangnya semua aspek khususnya aktifitas fisik serta motivasi belajar.

\section{DAFTAR PUSTAKA}

Anggani Sudono, 2000. Sumber Belajar dan Alat Permainan. Jakarta: Grasindo

Anggani Sudono, 2000. Sumber Belajar dan Alat Permainan. Jakarta: Grasindo

Arikunto, Suharsimi. 2006. Prosedur Penelitian Suatu Pendekatan Praktik. Jakarta : Rineka Cipta.

Badriah, Dewi Laelatul. 2002. Fisiologi Olahraga, Dalam Perfektif Teoritis dan Praktik. Bandung: Pustaka Ramadhan.

Budaya Jawa. (2018). "Oray-orayan Permainan Tradisional Jawa Barat". Dalam https://budayajawa.id/permainan-tradisionaljawa-barat-oray-orayan Oktober 2018.

Cahyono, Nuri. (2016). "Gobag Sodor". Dalam http://permatanusantara.blogspot.com/2009/02/gobagsodor.html Februari 2016.

Depdiknas. 2003. Kurikulum 2004 Standar Kompetensi Sekolah Dasar. Jakarta : Depdiknas.

Depdiknas. 2006. Peraturan Menteri Pendidikan Nasional Nomor 22 Tahun 2006. Tentang Standar Isi.

Djamarah, Syaiful Bahri. 2006. Strategi Belajar Mengajar. Jakarta: Rineka Cipta. 
Giriwijoyo (2007). Ilmu Kesehatan Olahraga. Untuk Kesehatan dan Untuk Prestasi Olahraga. FPOK UPI.

Harsono. 1988. Coaching dan Aspek-aspek Psikologi dalam Coaching. Jakarta: Tambak Kusuma.

Harsono. 2001. Latihan Fisik. Jakarta: Sekretariat KONI

Husdarta dan Yudha M. Saputra. Riduan (Editor) (2010). Belajar dan Pembelajaran Pendidikan Jasmani dan Kesehatan. Cet 1- Bandung. Dewa Ruci

http://proquest.umi.com/pqdweb?index

Kusmaedi, Nurlan (2010). Permainan Tradisional. Bandung: FPOK UPI Bandung

Lutan dan Cholik (1996/1997) Pendidikan Jasmani dan Kesehatan. Depdikbud. Dirjen Dikti. Bagian Proyek Penembangan Pendidikan Guru Sekolah Dasar. (Primary School Teacher Development Project) IBRD:Loan 3496-IND

Nurhasan dan Abdul Narlan. (2015). Tes dan Pengukuran Pendidikan Olahraga. Jurusan Pendidikan Jasmani, Kesehatan dan Rekreasi: Tasikmalaya

Marnes. (2015). "Manfaat Permainan Petak Umpet Bagi Tumbuh Kembang anak". Dalam https://www.marneskliker.com/2015/01/manfaa t-permainan-petak-umpet-bagi-tumbuhkembang-anak.html April 2015.

Rosdiani, Dini. Riduwan (Editor) (2013). Model pembelajran Langsung Dalam Pendidikan Jasmani dan Kesehatan, Bandung : Alfabeta

Samsudin. (2014). Media Pembelajaran pendidikan Jasmani. Jakarta ; Prenada Permata Grup.

Sanjaya, W. 2007. Strategi Pembelajaran Berorientasi Standar Proses Pendidikan. Prenada Media Group. Jakarta.

Sardiman A. M. (2003) . Interaksi dan Motivasi Belajar Mengajar. Jakarta: Rajawali Pers

Sardiman A. M. (2006) . Interaksi dan Motivasi Belajar Mengajar. Jakarta: Rajawali Pers.

Suherman, adang. Rusli Lutan (Editor) (2009). Revitalisasi Pengajran Dalm pendidikan Jasmani, Bandung. CV. Bintang Warli Artika.

Sumitra, DK dan Rohman Gumilar. (2017). Ragam Permainan Tradisional Pemersatu Bangsa. Bandung: PT. Duri Delco.

Sumardja, Dadan. (2015). "Kaulinan Urang Lembur". Dalam http://alamsantosa.blogspot.com/ April 2015.
Supandi.(2011). Menyiapkan Kesuksesan Anak Anda .Jakarta : Gramedia Pustaka Umum.

Sutresna, Nina. (2002). Pembelajaran Terpadu Sebagai Media Belajar Motorik Dan Matematik Dasar Pada Siswa SD. Bandung: FPOK UPI.

Tugas Sekolah Ku. (2017). "Permainan Boyboyan". Dalam http://prsekolahku.blogspot.com/2017/01/permainanboy-boyan.html\# Januari 2017. 